\title{
WATER BALANCE COMPONENTS IN COVERED AND UNCOVERED SOIL GROWING IRRIGATED MUSKMELON
}

\author{
Paulo Leonel Libardi ${ }^{(1)}$, Jaedson Cláudio Anunciato Mota ${ }^{(2)^{*}}$, Raimundo Nonato de Assis \\ Júnior $^{(2)}$, Alexsandro dos Santos Brito ${ }^{(3)}$ and Joaquim Amaro Filho ${ }^{(4)}$
}

(1) Universidade de São Paulo, Escola Superior de Agricultura Luiz de Queiroz, Departamento de Engenharia de Biossistemas, Piracicaba, São Paulo, Brasil.

(2) Universidade Federal do Ceará, Departamento de Ciências do Solo, Fortaleza, Ceará, Brasil.

(3) Instituto Federal Baiano, Campus Guanambi, Distrito de Ceraíma, Guanabi, Bahia, Brasil.

(4) Universidade Federal Rural do Semi-Árido, Departamento de Ciências Ambientais, Mossoró, Rio Grande do Norte, Brasil.

*Corresponding author.

E-mail: jaedson.mota@ufc.br

\begin{abstract}
Knowledge of the terms (or processes) of the soil water balance equation or simply the components of the soil water balance over the cycle of an agricultural crop is essential for soil and water management. Thus, the aim of this study was to analyze these components in a Cambissolo Háplico (Haplocambids) growing muskmelon (Cucumis melo L.) under drip irrigation, with covered and uncovered soil, in the municipality of Baraúna, State of Rio Grande do Norte, Brazil (05'04' 48" S, 37 37' 00" W). Muskmelon, variety AF-646, was cultivated in a flat experimental area $(20 \times 50 \mathrm{~m})$. The crop was spaced at $2.00 \mathrm{~m}$ between rows and $0.35 \mathrm{~m}$ between plants, in a total of ten $50-\mathrm{m}$-long plant rows. At points corresponding to $1 / 3$ and $2 / 3$ of each plant row, four tensiometers (at a distance of $0.1 \mathrm{~m}$ from each other) were set up at the depths of $0.1,0.2,0.3$, and $0.4 \mathrm{~m}$, adjacent to the irrigation line $(0.1 \mathrm{~m}$ from the plant row $)$, between two selected plants. Five random plant rows were mulched using dry leaves of banana (Musa sp.) along the drip line, forming a 0.5-m-wide strip, which covered an area of $25 \mathrm{~m}^{2}$ per of plant row with covered soil. In the other five rows, there was no covering. Thus, the experiment consisted of two treatments, with 10 replicates, in four phenological stages: initial (7-22 DAS - days after sowing), growing (22-40 DAS), fruiting (40-58 DAS) and maturation (58-70 DAS). Rainfall was measured with a rain gauge and water storage was estimated by the trapezoidal method, based on tensiometer readings and soil water retention curves. For soil water flux densities at 0.3 $\mathrm{m}$, the tensiometers at the depths of $0.2,0.3$, and $0.4 \mathrm{~m}$ were considered; the tensiometer at 0.3 m was used to estimate soil water content from the soil water retention curve at this depth, and the other two to calculate the total potential gradient. Flux densities were calculated through use of the Darcy-Buckingham equation, with hydraulic conductivity determined by the
\end{abstract}


instantaneous profile method. Crop actual evapotranspiration was calculated as the unknown of the soil water balance equation. The soil water balance method is effective in estimating the actual evapotranspiration of irrigated muskmelon; there was no significant effect of soil coverage on capillary rise, internal drainage, crop actual evapotranspiration, and muskmelon yield compared with the uncovered soil; the transport of water caused by evaporation in the uncovered soil was controlled by the break in capillarity at the soil-atmosphere interface, which caused similar water dynamics for both management practices applied.

Keywords: water management, evapotranspiration, internal drainage, Apodi Plateau.

\title{
RESUMO: COMPONENTES DO BALANÇO DE ÁGUA EM SOLO COBERTO E DESNUDO CULTIVADO COM MELÃO IRRIGADO
}

\begin{abstract}
O conhecimento dos termos (ou processos) da equação do balanço de água no solo ou simplesmente os componentes do balanço de água no solo no longo do ciclo de uma cultura agrícola é essencial para o manejo de solo e da água. Assim, esta pesquisa teve o objetivo de estudar esses componentes em um Cambissolo Háplico cultivado com meloeiro (Cucumis melo L.) irrigado por gotejamento, com e sem cobertura, no município de Baraúna, Estado do Rio Grande do Norte, Brasil (05 $04^{\prime} 48^{\prime \prime} S, 37^{\circ} 37^{\prime} 00^{\prime \prime} W$ ). $O$ meloeiro, variedade AF-646, foi cultivado em uma área experimental plana $(20 \times 50 \mathrm{~m})$. A cultura foi espaçada de 2,00 m entre linhas e 0,35 m entre plantas, totalizando 10 fileiras de plantas de $50 \mathrm{~m}$ de comprimento. Nos pontos correspondentes a $1 \frac{1}{3}$ e $2 \frac{1}{3}$ de cada linha de plantas, quatro tensiômetros foram instalados, nas profundidades de 0,1;0,2;0,3; e 0,4 $\mathrm{m}$, adjacentes à linha de irrigação $(0,1 \mathrm{~m}$ da linha de plantas), entre duas plantas selecionadas, a 0,1 m de distância. Em cinco linhas aleatórias, fez-se a cobertura com folhas secas de bananeira (Musa sp.) no longo da linha de gotejamento em uma faixa de 0,5 m, definindo uma área coberta de $25 \mathrm{~m}^{2}$. Nas outras cinco linhas, não houve cobertura. Assim, o experimento consistiu de dois tratamentos, com 10 repetições, em quatro estádios fenológicos: inicial (7-22 DAS - dias após a semeadura), crescimento (22-40 DAS), frutificação (40-58 DAS) e maturação (58-70 DAS). A precipitação foi medida com pluviômetro, e o armazenamento de água estimado pelo método do trapézio, a partir das leituras dos tensiômetros e das curvas de retenção da água no solo. Para determinar a densidade de fluxo de água em $0,3 \mathrm{~m}$, foram considerados os tensiômetros nas profundidades de 0,2; 0,3; e 0,4 m. O tensiômetro a 0,3 m foi utilizado para estimar o conteúdo de água no solo, com uso da curva de retenção de água para essa profundidade, e os outros dois para o cálculo do gradiente de potencial total. As densidades de fluxo foram calculadas pela equação de Darcy-Buckingham, com a condutividade hidráulica do solo determinada pelo método do perfil instantâneo. A evapotranspiração real foi calculada como sendo a incógnita da equação do balanço de água no solo. O método do balanço de água no solo é eficaz na estimativa da evapotranspiração real de melão irrigado; não houve efeito significativo da cobertura do solo na ascensão capilar, drenagem interna, evapotranspiração real e produtividade de melão em comparação ao manejo com não cobertura do solo. A transferência de água por evaporação em solo desnudo se evidenciou controlada pela quebra da capilaridade na interface solo-atmosfera, o que fez com que a dinâmica da água em ambos os manejos aplicados fosse semelhante.
\end{abstract}

Palavras-chave: manejo de água, evapotranspiração, drenagem interna, Chapada do Apodi.

\section{INTRODUCTION}

The muskmelon crop plays an important role in fruit exports from Brazil. For the State of Rio Grande do Norte, which is one of the major fruit exporters in Brazil, fruit growing is the second largest source of income. Data from the Instituto Brasileiro de Geografia e Estatística (IBGE, 2014) indicate that in 2012 , production was $575,386 \mathrm{t}$ in an area of $22,789 \mathrm{ha}$, representing a yield of $25.248 \mathrm{Mg} \mathrm{ha}^{-1}$.

Soil water balance differs from the known climatological water balance. While the former is based on in situ water measurements, the later provides an estimate based on climatological data from a time series (Reichardt, 1990). One of the disadvantages of using climatological water balance is the high spatial variability that a series can contain. In a study comparing water balances based on climatological data with real soil conditions, in which crop evapotranspiration, soil water storage, water holding capacity, internal drainage, and surface runoff were estimated for a two-year period for coffee plants, Bruno et al. (2007) found that the climatological water balance underestimates these variables.

The water balance is essential for making rational decisions regarding water management and conservation (Burt, 1999). Although, none of 
the components of the soil water balance equation is easily measured with accuracy (Blight, 2003), and Aydin (1994) considers the need for estimating them because of the importance that each one has when analyzed separately. To emphasize the relevance of the subject, Valnir Júnior et al. (2001) report that studies on water balance are essential for providing information on the leaching of chemical elements in the soil and on groundwater pollution. Researchers comment on leaching of nutrients using the water balance to estimate losses (Ghiberto et al., 2009, 2011a, 2015).

Management of water resources in the muskmelon-producing region in the States of Ceará and Rio Grande do Norte does not prioritize water savings, shown by the wide variation in irrigation depth, which ranges from 5 to $13 \mathrm{~mm} \mathrm{~d}^{-1}$ (Crisóstomo et al., 2002). In order to correct this management practice, Paramasivam et al. (2000) comment that accurate soil water content measurements are required for adequate water application, so that water deficit in the root zone of the soil profile receives water supply. Most growers, according to Marouelli et al. (2003), prefer an easier irrigation practices instead of using rational methods of water management.

The prevailing method of water application in most muskmelon-producing states in Brazil is drip irrigation, which is characterized by the application of known volumes of water close to the plant stem that are ideal for the crop and vary over its development (Medeiros et al., 2005). The fact that localized irrigation wets just a fraction of the soil surface, which greatly reduces evaporation, especially when the crop does not yet cover the entire soil surface (Allen et al., 1998).

Both natural and synthetic soil coverage, a priori, consists of a physical impediment to energy and water vapor transfer to the atmosphere. From a soil conservation perspective, Anjos et al. (2003) suggested that the maintenance of crop residues or mulch on the soil surface prevents surface crusting, reduces runoff, and thus erosion, increases soil water availability, reduces soil temperature, and allows favorable conditions for root development.

Assuming that: a) it is possible to measure muskmelon actual evapotranspiration by the soil water balance method; b) soil coverage increases water losses by internal drainage, and reduces soil water input through capillary rise and soil water output through evapotranspiration in muskmelon in two management systems (with covered and uncovered soil) in a flat area receiving the same rainfall and irrigation water inputs, the aim of this study was to measure the component processes of the soil water balance equation in a Cambissolo Háplico (Haplocambids) planted to muskmelon under drip irrigation, with covered and uncovered soil.

\section{MATERIAL AND METHODS}

The experiment was carried out in the Apodi Plateau in a Cambissolo Háplico (Haplocambids) (Table 1), in the municipality of Baraúna, State of Rio Grande do Norte, Brazil (05 04' 48” S, 37 37' 00” W). Yellow muskmelon (Cucumis melo L.), variety AF-646, at a spacing of $2.00 \times 0.35 \mathrm{~m}$, was grown in 10 50 -m-long plant rows in a flat area $(20 \times 50 \mathrm{~m})$. At the points corresponding to $1 / 3$ and $2 / 3$ of each plant row, four tensiometers (at a distance of $0.1 \mathrm{~m}$ from each other) were set up at the depths of $0.1,0.2,0.3$, and $0.4 \mathrm{~m}$ (which include most of the effective roots of the muskmelon), adjacent to the irrigation line ( $0.1 \mathrm{~m}$ from the plant row) between two selected plants (Figure 1).

Five plant rows were covered with dried leaves of banana (Musa sp.) along the drip line, forming a $0.5 \mathrm{~m}$-wide strip, which covered an area of $25 \mathrm{~m}^{2}$ for each of these five rows. The other five rows

Table 1. Soil physical properties: granulometry, textural class, soil bulk density - Bd, particle density - Pd, and pore volume (macropore - macro, micropore - micro, and total pore) in a Cambissolo Háplico

\begin{tabular}{|c|c|c|c|c|c|c|c|c|c|c|c|c|c|c|}
\hline \multirow{2}{*}{ Depth } & \multicolumn{6}{|c|}{ Sand ${ }^{(1)}$} & \multirow{2}{*}{ Silt } & \multirow{2}{*}{ Clay } & \multirow{2}{*}{$\begin{array}{l}\text { Textural } \\
\text { class }\end{array}$} & \multirow{2}{*}{ Bd } & \multirow{2}{*}{ Pd } & \multicolumn{3}{|c|}{ Pore volume } \\
\hline & VC & $\mathbf{C}$ & $\mathbf{M}$ & $\mathbf{F}$ & VF & Total & & & & & & Macro & Micro & Total \\
\hline $\mathrm{m}$ & \multicolumn{8}{|c|}{$\mathrm{g} \mathrm{kg}^{-1}$} & & \multicolumn{2}{|c|}{$\mathrm{Mg} \mathrm{m}^{-3}$} & \multicolumn{3}{|c|}{$\mathrm{m}^{3} \mathrm{~m}^{-3}$} \\
\hline 0.1 & 96 & 81 & 89 & 71 & 33 & 370 & 80 & 550 & Clay & 1,690 & 2,590 & 6 & 29 & 35 \\
\hline 0.2 & 129 & 107 & 117 & 87 & 40 & 480 & 70 & 450 & Clay & 1,530 & 2,580 & 13 & 28 & 41 \\
\hline 0.3 & 149 & 109 & 113 & 88 & 41 & 500 & 60 & 440 & Clay & 1,420 & 2,590 & 15 & 30 & 45 \\
\hline 0.4 & 128 & 102 & 106 & 85 & 39 & 460 & 100 & 440 & Clay & 1,360 & 2,590 & 16 & 31 & 47 \\
\hline 0.5 & 154 & 115 & 116 & 87 & 38 & 510 & 60 & 430 & Clay & 1,380 & 2,580 & 21 & 26 & 47 \\
\hline 0.6 & 130 & 105 & 113 & 97 & 45 & 490 & 80 & 430 & Clay & 1,420 & 2,590 & 10 & 35 & 45 \\
\hline 0.7 & 106 & 88 & 93 & 85 & 38 & 410 & 70 & 520 & Clay & 1,430 & 2,540 & 11 & 33 & 44 \\
\hline
\end{tabular}

(1) VC: very coarse (2.00 - >1.00 mm); C: coarse (1.00 - >0.50 mm); M: medium (0.50 - >0.25 mm); F: fine (0.25 - >0.10 mm); VF: very fine $(0.10 \mathrm{~mm}->0.053 \mathrm{~mm})$. 


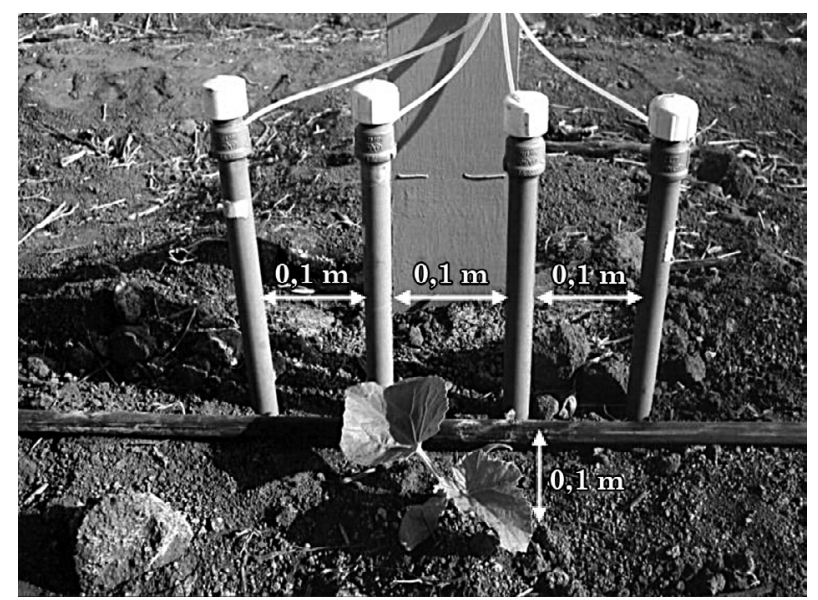

Figure 1. Placement of tensiometers in relation to the plant and the irrigation line.

remained uncovered. The experiment consisted of two treatments: with and without mulch, with ten replicates - 10 sets of four tensiometers; and four phenological stages: initial (7-22 DAS - days after sowing), vegetative (22-40 DAS), fruiting (40-58 DAS) and maturation (58-70 DAS).

Three soil pits of $1 \mathrm{~m}^{2}(1 \times 1 \mathrm{~m})$ and $0.7 \mathrm{~m}$ of depth were opened for collecting disturbed and undisturbed soil samples at the depths of 0.1 , $0.2,0.3,0.4,0.5,0.6$, and $0.7 \mathrm{~m}$. The undisturbed soil samples were collected in volumetric rings, with an Uhland soil sampler (height $=0.03 \mathrm{~m}$ and diameter $=0.0537 \mathrm{~m}$ ).

Disturbed soil samples were analyzed for particle size distribution; clay was analyzed through the pipette method, sand through sieving, and silt by the difference between the clay and sand fractions (Gee and Bauder, 1986). Particle density was analyzed through the volumetric flask method (Blake and Hartge, 1986a) and part of the soil water retention curves in Richards' chambers, at the tensions of $33 ; 50 ; 100 ; 300 ; 600 ; 900 ; 1,200$; and $1,500 \mathrm{kPa}$ (Klute, 1986). The points of the soil water retention curve at the tensions of $2,4,6,8$, and $10 \mathrm{kPa}$ in a Haines funnel (Klute, 1986), and soil bulk density (Blake and Hartge, 1986b) were determined in the undisturbed soil samples. The data of the water retention curve obtained in the laboratory were fitted to the model of van Genuchten (1980),

$\theta=\theta_{r}+\frac{\theta_{s}-\theta_{r}}{\left[1+\left(\alpha\left|\phi_{m}\right|\right)^{n}\right]^{m}}$

where $\theta r$ and $\theta s$ are the residual and saturation water contents $\left(\mathrm{m}^{3} \mathrm{~m}^{-3}\right)$, respectively; $\phi_{m}$, the soil water matric potential $(\mathrm{kPa})$; $\alpha$, the scaling factor for $\phi m$; and $m$ and $n$, variables related to the shape of the curve. The software SWRC, version 2.0, was used, fixing the variables $\theta s$ and $\theta r$ at the water contents at saturation and at the tension of $1,500 \mathrm{kPa}$, respectively, measured in the laboratory. The parameters $a, m$, and $n$ were adjusted through the Newton-Raphson iterative method, with no dependence between $m$ and $n$ (Dourado Neto et al., 2000).

Soil total porosity was obtained by TP $=[1-(\rho s / \rho p)]$, were TP is soil porosity $\left(\mathrm{m}^{3} \mathrm{~m}^{-3}\right)$, and $\rho s$ and $\rho p$ are soil bulk density and particle density, respectively $\left(\mathrm{Mg} \mathrm{m}^{-3}\right)$. In the soil water retention curve, the water content at saturation was considered as equal to the total porosity. Microporosity (pores with diameter $\leq 50 \mu \mathrm{m}$ ) was determined in a Haines funnel through the application of a $6-\mathrm{kPa}$ tension on the samples, until the water occupying these pores was drained (Danielson and Sutherland, 1986). Macroporosity was calculated by the difference between total porosity and the volume of pores with diameter smaller than $50 \mu \mathrm{m}$. All determinations were performed in three replicates.

The tensiometers were read every day between 6 and 7 a.m. Readings were converted to matric potential and then to water content through the fitting equation for soil water retention curves for the corresponding depth.

Soil water balance, defined as the difference between the amount of water entering the control volume and the amount of water that leaves it in a certain time interval (Libardi, 2012), was calculated in this case through the equation

$(P+I+C R)-\left(D+E T_{a c}\right)=\Delta S$

Eq. 2

where $\mathrm{P}$ is rainfall $(\mathrm{mm})$; $\mathrm{I}$, irrigation $(\mathrm{mm})$; CR, capillary rise $(\mathrm{mm})$; D, internal drainage $(\mathrm{mm})$; $\mathrm{ET}_{\mathrm{ac}}$, actual crop evapotranspiration $(\mathrm{mm})$; and $\Delta \mathrm{S}$, balance or variation in soil water storage $(\mathrm{mm})$. The control volume was considered as the soil surface and the depth of $0.3 \mathrm{~m}$ as its upper and lower limits, respectively. This soil layer includes almost all of the effective roots of muskmelon plants (Pedrosa, 1997).

Rainfall was measured with a rain gauge set up in the experimental area and was converted to effective rainfall that effectively entered the control volume of soil utilized by the roots by means of equation 3 proposed by the USDA Soil Conservation Service (Clarke, 1998) for estimation of irrigation needs in the region where this experiment was conducted:

$P_{\text {ef }}=P\left(1-1.6 \times 10^{-3} P\right)$

Eq. 3

where $P_{e f}$ is the effective rainfall ( $\left.\mathrm{mm}\right)$ and $P$ is the rainfall measured with the rain gauge.

Drip irrigation was managed to prevent soil water tension from reaching values greater than $40 \mathrm{kPa}$. Water depth was calculated by dividing the applied water volume by the wetted area on the soil surface, assuming a square area of side $\mathrm{L}$ equal to $0.35 \mathrm{~m}$, with the dripper at its center. In the center of the soil ridge, a $0.35 \mathrm{~m}$-wide wetted strip is formed, which is 
as long as the dripline. Thus, the wetted area of each plant was $0.35 \times 0.35 \mathrm{~m}\left(0.1225 \mathrm{~m}^{2}\right)$, whose fraction is 0.175 in relation to the area available to the plant $\left(0.7 \mathrm{~m}^{2}\right)$. This fraction, or the wetness factor, was used to estimate the actual evapotranspiration per unit of soil area utilized by the crop.

Internal drainage, or capillary rise, was estimated by the Darcy-Buckingham equation (Equation 4) according to Libardi (2012),

$q_{z}=-K(\theta)\left[\frac{\phi_{t(0.2 m)}-\phi_{t(0.4 m)}}{0.2}\right]$

where $K(\theta)$ is hydraulic conductivity as a function of soil water content $\theta$, at the depth of $0.3 \mathrm{~m}$ $[K(\theta)=144.32 \exp 43.503(\theta-0.381)] ; \phi_{t(0.2 m)}$ and $\phi_{t(0.4 m)}$ are the total potentials at depths of 0.2 and $0.4 \mathrm{~m}$; and $0.2 \mathrm{~m}$ is the soil thickness, in $\mathrm{m}$, between these depths.

Water storage was estimated daily by the trapezoidal rule, using equation 5 (Libardi, 2012):

$$
\mathrm{S}_{\mathrm{z}}=\left[\left(1.5 \theta_{0.1 \mathrm{~m}}+\theta_{0.2 \mathrm{~m}}+0.5 \theta_{0.3 \mathrm{~m}}\right) .0 .1\right] \times 1000 \text { Eq. } 5
$$

where $S_{z}$ is soil water storage, in $\mathrm{mm}$, and $\theta_{0.1 \mathrm{~m}}$, $\theta_{0.2 m}$, and $\theta_{0.3 m}$ are the water contents, in $\mathrm{m}^{3} \mathrm{~m}^{-3}$, at depths of $0.1,0.2$, and $0.3 \mathrm{~m}$, respectively.

The actual crop evapotranspiration $\left(\mathrm{ET}_{\mathrm{ac}}\right)$ was the unknown of the water balance equation. During $\mathrm{ET}_{\mathrm{ac}}$ estimation by the soil water balance equation, $\mathrm{ET}_{0}$ measurements were taken daily by the Class A Pan method $\left(\mathrm{E}_{\mathrm{CA}}\right)$, aiming to obtain the relationship between $\mathrm{ET}_{0}$ and $\mathrm{ET}_{\mathrm{ac}}\left(\mathrm{K}_{\mathrm{ac}}\right)$ for the different phenological stages. The tank coefficient, according to Bernardo et al. (2008), was considered as 0.75 (tank set up in an uncultivated area, relative air humidity of 40-70\%, moderate wind speed, and side border of bare soil of $1 \mathrm{~m}$ ).

To fit the $\mathrm{K}_{\mathrm{ac}}$ curve over time, the following criteria were adopted (Medeiros et al., 2005): for Phase I, the average $K_{a c}$ was considered for the $2^{\text {nd }}, 3^{\text {rd }}$, and $4^{\text {th }}$ weeks after sowing (8-28 days); for Phase II, a linear regression equation was fitted for $\mathrm{K}_{\mathrm{ac}}$ for the $4^{\text {th }}, 5^{\text {th }}$, $6^{\text {th }}$, and $7^{\text {th }}$ weeks (22-49 days); for Phase III, the average values of the $7^{\text {th }}$ and $8^{\text {th }}$ weeks (43-56 days) were considered; and, finally, for Phase IV, the fitting of a linear regression equation of $\mathrm{K}_{\mathrm{ac}}$ was considered for the $8^{\text {th }}, 9^{\text {th }}$, and $10^{\text {th }}$ weeks (50-70 days). Knowing the limits of each growth stage, the curve was traced by the intersection of the lines.

At the end of the experiment, yield and water use efficiency (WUE) were evaluated. The WUE was calculated as the ratio between yield and water consumption in the crop cycle, represented by $\mathrm{ET}_{\mathrm{ac}}$, estimated from the water balance equation

$$
\text { WUE }\left(k g \mathrm{~m}^{-3}\right)=\frac{\text { Yield }\left(k g h a^{-1}\right)}{\text { Water consumption }\left(\mathrm{m}^{3} h a^{-1}\right)} \text { Eq. } 6
$$

Data were analyzed using descriptive statistics, in order to verify the existence of outlying observations (outliers) that could impair the average behavior of the evaluated components, and were subjected to the normality test (Kolmogorov-Smirnov $5 \%$ ), analysis of variance (F test) in a $2 \times 4$ factorial design (two represents the soil surface conditions - with or without mulch; four represents the phenological stages - initial, vegetative, fruiting, and maturation) with ten replicates in a completely randomized design. Means were compared by Tukey test at $5 \%$.

\section{RESULTS AND DISCUSSION}

\section{Rainfall (P) and irrigation (I)}

Rainfall values from a time series of 39 years (1970-2008) were compared with those observed in the experimental area (Figure 2). The time series data come from weather stations in Jaguaruana, $\mathrm{CE}$, and Mossoró, RN, about $30 \mathrm{~km}$ away from the experimental area, each one covering a radius of $150 \mathrm{~km}$ (Inmet, 2008). Since the experimental area is located nearly half way between the two stations, the average of their monthly rainfall data was used for comparison with the observed data in the experimental area.

Apparently, January was atypical regarding rainfall, since the observed data of 39 years indicate the occurrence of $65.9 \mathrm{~mm}$, which was not observed during the experiment. However, for the semiarid region and muskmelon cultivation, this atypicality does not compromise the interpretation of soil water balance results since January is not considered a month of the "rainy season", and therefore changes in rainfall are considered normal for this period.

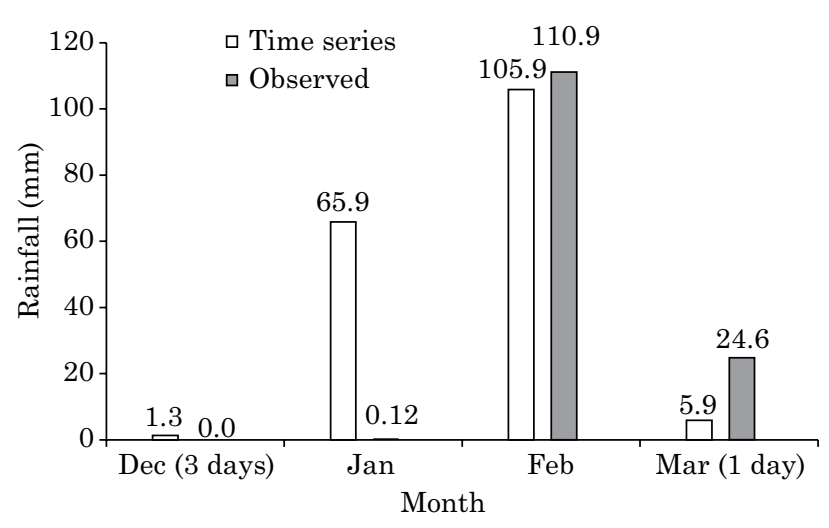

Figure 2. Rainfall from a time series and from the data observed in the experimental area. 
The amounts of water applied, considering only the wetted area, were $149 \mathrm{~mm}, 320 \mathrm{~mm}, 831 \mathrm{~mm}$, and $105 \mathrm{~mm}$ for the initial, vegetative, fruiting, and maturation stages, respectively, for a total of $1,405 \mathrm{~mm}$ throughout the cycle. It should be noted that because of the rainfall recorded for the maturation stage, the water applied by irrigation for this period does not reflect the water management using tensiometers and hence the water requirement of the crop.

Comparing the amount of water applied by irrigation in the experiment with the volume usually applied to the muskmelon crop in the Apodi Plateau (Figure 3), the management practice using tensiometers seemed to enable a reduction in water supply for all periods, with no yield loss, as will be shown later. The amount of water applied by irrigation based on soil water monitoring with tensiometers, when corrected for the area utilized by the plant $(2.00 \times 0.35 \mathrm{~m})$, was $246 \mathrm{~mm}$, thus very similar to that observed by some authors for the muskmelon crop. Some examples are the studies of MacGillivray (1951), working with water depths in Davis, California, United States, in which the highest yields were obtained with water depths ranging from 152 to $254 \mathrm{~mm}$ per cycle of the muskmelon; in the Curu Valley in Pentecoste, CE, Brazil, Barros et al. (2002) observed maximum yield of yellow melon (AF-682) with a water depth of $222 \mathrm{~mm}$; and in an Argissolo Vermelho-Amarelo in the municipality of Mossoró, $\mathrm{RN}$, Brazil, thus in the same region where this experiment was conducted, Medeiros et al. (2007) applied a standard water depth of $270 \mathrm{~mm}$ for a Cantaloupe melon crop, with a very similar distribution for the same phenological periods.

Considering the sum of irrigation and effective rainfall $(375 \mathrm{~mm})$ that occurred in the experimental area during periods of soil water balance, the initial and vegetative periods received water only through irrigation. The fruiting period also had

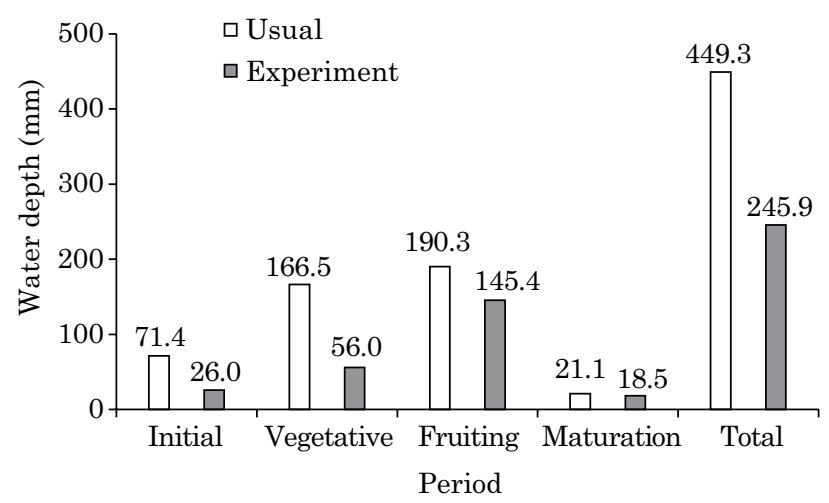

Figure 3. Usual water depths for muskmelon cultivation in the Apodi Plateau and those applied in the experimental area. water application through irrigation in $99 \%$ of its duration, indicated by the tensiometers. During maturation, the contribution from rainfall was equal to $53 \%$, thus eliminating the continuous use of tensiometers to guide water application. For the initial, vegetative, fruiting, and maturation periods, water savings were $64,66,24$, and $12 \%$, respectively. Considering the whole crop cycle, applied irrigation water was reduced by $45 \%$, which is equivalent to $203 \mathrm{~mm}$ or $2,030 \mathrm{~m}^{3} \mathrm{ha}^{-1}$.

Since agribusiness is a competitive activity, and so is fruit growing, a reduction of $45 \%$ in water supply, with no reduction in crop yield, means not only a better use of water resources, fertilizers, and pesticides, but also a reduction in consumption of manual labor and electricity. The water extracted from the Jandaíra limestone in the Apodi Plateau costs US $\$ 0.023$ per $\mathrm{m}^{3}$ (Porto Filho et al., 2006). In this context, the reduction of $2,034 \mathrm{~m}^{3} \mathrm{ha}^{-1}$ means a saving of US $\$ 47 \mathrm{ha}^{-1}$. Moreover, charges have been placed by the government on water use for irrigated agriculture in some parts of Brazil, and there is the possibility that this will be extended throughout Brazil (Abad, 2007).

This situation highlights the need for better management of water resources in muskmelon cultivations, for two main reasons. First is the environmental issue, since there is very strong pressure from environmental protection agencies regarding water conservation around the world. Second is the consideration that agriculture is a commercial activity and therefore aims at profit, which requires reduced costs. Therefore, investing in equipment to monitor soil water dynamics is an important step in restricting spending in an agricultural enterprise. From the instrumentation perspective, the tensiometer, is a device that works very well for monitoring water in soil (Paramasivam et al., 2000), allowing improvement of irrigation in crops that depend on this practice.

\section{Variation of soil water storage $\left(\Delta S_{z}\right)$}

The variations in daily storage in the tensiometer bulb (Figure 4) were similar in the tillage systems over time, which generally reflects the water applied to the soil through irrigation and rainfall, confirming that the variation in storage follows the variation in rainfall (Antonino et al., 2000; Lima et al., 2006). It is important to point out the homogeneity of the soil in the area (Table 1), which in this case was not an expressive source of variation to affect the results, i.e., the variation in the data for water storage in the 0.0-0.3 m layer was due to the applied treatments, as well as other factors, such as variations in water distribution via irrigation. Details of the discussion on the variation of water storage in the soil of this experiment are presented by Mota et al. (2010).

Coefficients of variation (CV) were calculated daily for each treatment and, based on the criterion 
of Warrick and Nielsen (1980) (low - CV $<12 \%$; average - $12 \%<\mathrm{CV}<60 \%$; high - $\mathrm{CV} \geq 60 \%$ ), the results showed from medium to high variability. One explanation for this is that, as there were ten replicates in the experiment and irrigation was managed to keep the soil at about the same water content, small changes in storage can lead to high coefficients of variation. However, although the uncertainty of the determination of the change in storage can be high, the absolute values are small and do not significantly affect the calculation of any other component that is left as unknown in the soil water balance equation (Reichardt et al., 1993).

\section{Internal drainage (D) and capillary rise (CR)}

Considering the monitoring of soil water content through tensiometers for the $0.0-0.3 \mathrm{~m}$ layer and the matric potential of $33 \mathrm{kPa}$, the soil water content remained mostly above field capacity for both covered and uncovered soil (Figure 5), which explains the occurrence of drainage flows in both situations. It may be seen that drainage was higher in the covered soil (Table 2), $35 \mathrm{~mm}$ more than in the uncovered soil, precisely because the soil water content in this management system was higher during most of the monitoring days, which caused drainage to be numerically higher when the two soil management situations were compared.

The observed data represent what occurred in the area wetted by the drip system and not the area available to the plant (see Figure 6 and Table 2). Flux densities were mostly downward and did not differ between treatments. Moreover, data from each treatment showed higher internal drainage, but did not differ significantly in the growing and fruiting periods, which are characterized by the application of larger volumes of water to the muskmelon.

Internal drainage values in soils with mulch (Table 2) amounted to about $43,26,13$, and $11 \%$ of the water volumes applied in the initial, vegetation, fruiting, and maturation stages, respectively. In bare soil, values were not statistically different from the situation of uncovered soil and corresponded to $36,22,12$, and $5 \%$ for the respective periods. Considering the total internal drainage in the whole cycle, the correspondence is 19 and $17 \%$ of the total volume applied in soil with and without coverage of the wet strip, respectively.

The results indicate that, although the water supply to the crop was rigorously monitored, the internal drainage was high, especially in the initial stage. It so happens that, as previously discussed, water consumption by the crop in the initial stage, considering only its transpiration, is very small. This causes the applied excess water to be lost by evaporation or internal drainage. Since evaporation was hampered in covered soil and capillarity may have been broken in bare soil, water losses in both farming systems occurred preferentially through deep drainage.

In order to better control the internal drainage in those periods in which leaf area is small, thus with little water loss through transpiration, irrigation should be as frequent as possible. In this experiment,

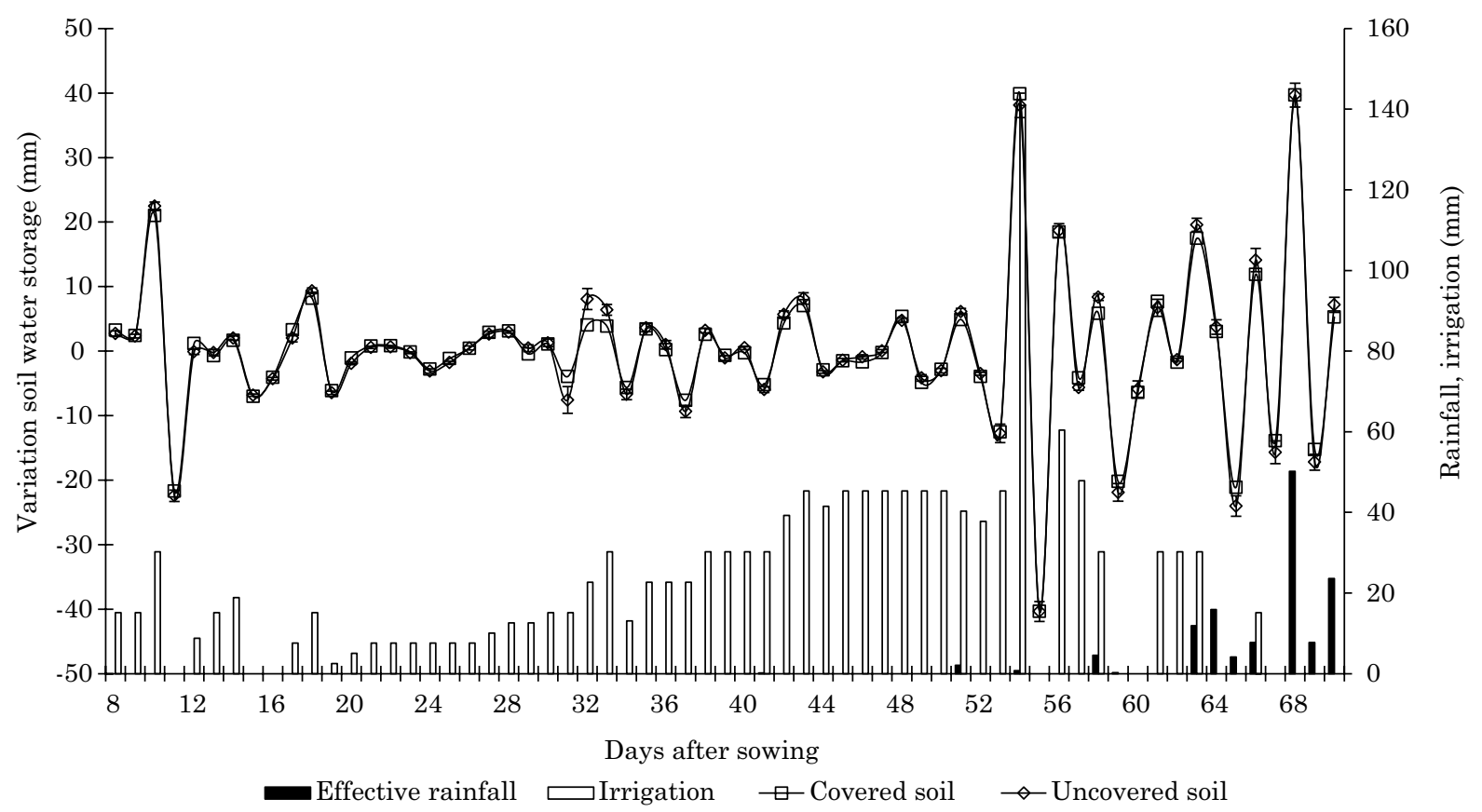

Figure 4. Average daily variation in soil water storage, with the corresponding standard deviations throughout the muskmelon cycle. 


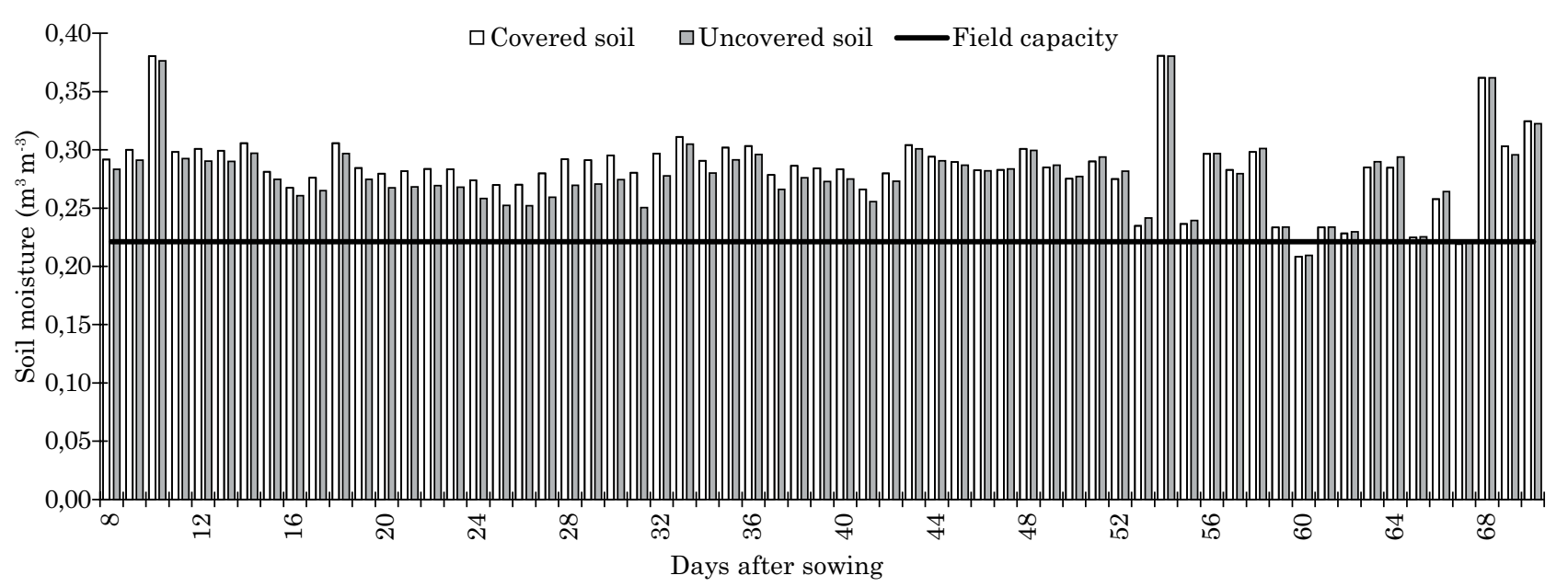

Figure 5. Soil water content throughout the experiment.

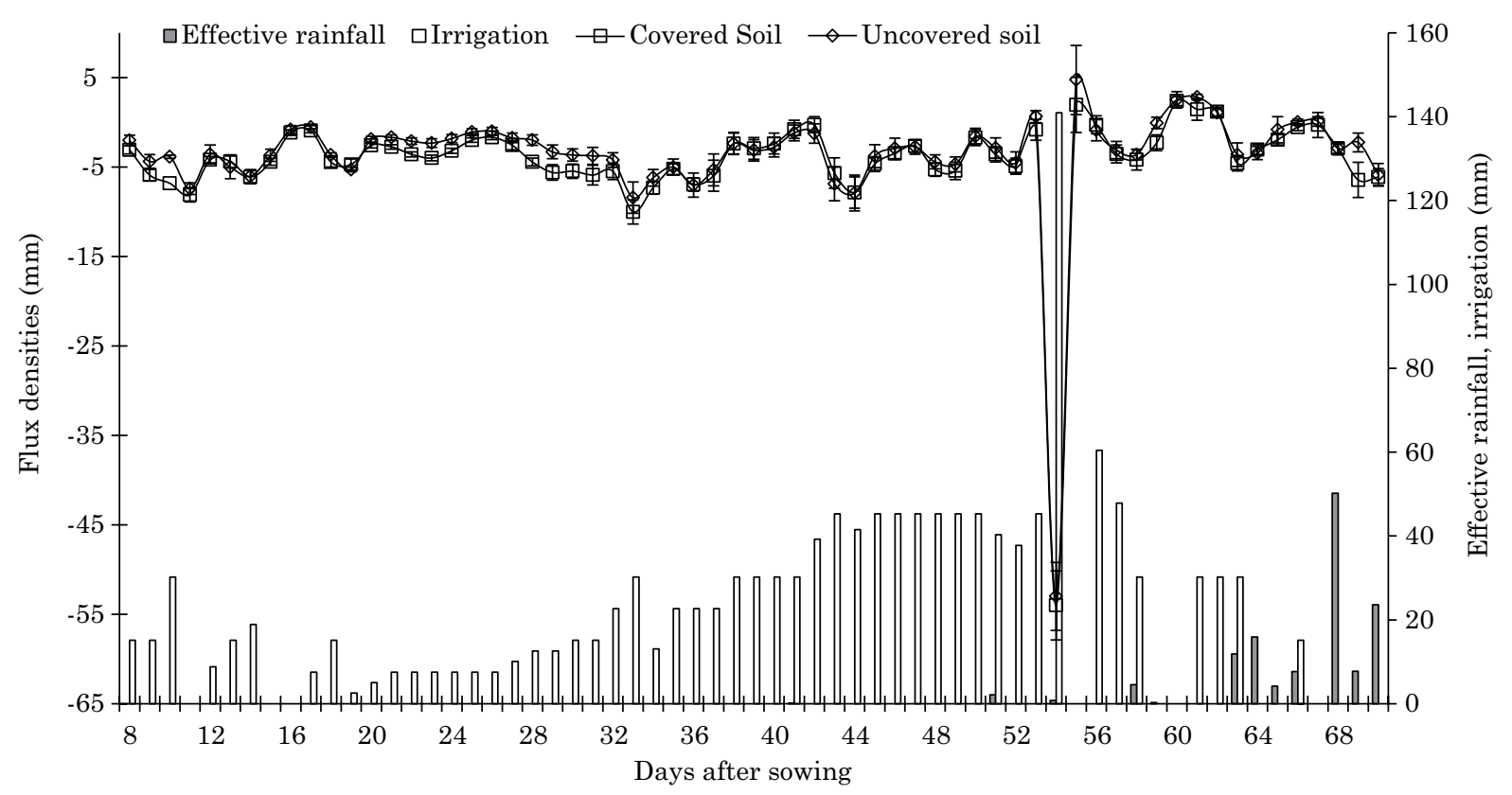

Figure 6. Average daily flux density, with the correspondent standard deviations, rainfall, and irrigation throughout the muskmelon cycle (negative values indicate internal drainage; positive values indicate capillary rise).

although each daily water application time was much lower compared to that commonly practiced in melon-producing regions in the States of Rio Grande do Norte and Ceará, a single application frequently contributes to water losses by internal drainage beyond the required leaching volume. Therefore, it is wise to adopt a management practice with short times of irrigation, though it is necessary to increase the frequency, optimize water use, and prevent contamination of groundwater with chemical pollutants. Another possibility is to keep the irrigation system in operation for a longer time, provided that the drippers have a low flow rate (it is important to note that the soil surface must be covered to prevent water loss through evaporation, since it will be kept moist for a longer time).

During the fruiting period, the drained water was enough to leach salts that may have been present from the root zone and it reflects the irrigation management practice using tensiometers very well. Internal drainage during the maturation period resulted primarily from rainfall since the process of reduction in the water supply to increase sugar concentration in fruits, under normal conditions of cultivation, begins in this stage. Internal drainage prevailed throughout the crop cycle, for the reasons 
Table 2. Rainfall (P), irrigation (I), capillary rise (CR), internal drainage (D), variation of soil water storage $(\triangle S)$, actual $\left(E T_{a c}\right)$ and reference $\left(E T_{0}\right)$ crop evapotranspiration, and actual crop coefficient $\left(K_{a c}\right)$ for muskmelon, in covered and uncovered soil

\begin{tabular}{|c|c|c|c|c|c|c|c|c|c|}
\hline Period & Day & $\mathbf{P}$ & $\mathbf{I}$ & CR/D & $\Delta \mathbf{S}$ & $\mathrm{ET}_{\mathrm{ac}}$ & $\mathrm{ET}_{0}$ of the period & Daily $\mathrm{ET}_{\mathrm{ac}}{ }^{(1)}$ & $\mathbf{K}_{\mathrm{ac}}^{(2)}$ \\
\hline & & \multicolumn{7}{|c|}{$\mathbf{m m}$} & \\
\hline & & \multicolumn{8}{|c|}{ Covered soil } \\
\hline Initial & 15 & 0 & 148 & $-63 \mathrm{abA}(6)$ & $2(1)$ & $83 \mathrm{cA}(6)$ & 108 & 0.97 & 0.13 \\
\hline Vegetative & 18 & 0 & 320 & -82 aA (11) & $-1(1)$ & $240 \mathrm{bA}(11)$ & 132 & 2.33 & 0.32 \\
\hline Fruiting & 18 & 7 & 831 & -107 aA (14) & $5(1)$ & 726 aA (13) & 119 & 7.06 & 1.07 \\
\hline Maturation & 12 & 121 & 106 & $-24 \mathrm{bA}(5)$ & $6(1)$ & $197 \mathrm{bA}(5)$ & 59 & 2.87 & 0.58 \\
\hline \multirow[t]{4}{*}{ Total } & 63 & 128 & 1,405 & -276 A (37) & $12(4)$ & $1,246 \mathrm{~A}(364)$ & 418 & 3.46 & 0.52 \\
\hline & & & & $\mathrm{CR}=18 \mathrm{~A}$ & & & & & \\
\hline & & & & $\mathrm{D}=-294 \mathrm{~A}$ & & & & & \\
\hline & & \multicolumn{8}{|c|}{ Uncovered soil } \\
\hline Initial & 15 & 0 & 148 & $-53 \mathrm{bcA}(6)$ & $0(0)$ & $96 \mathrm{cA}(6)$ & 108 & 1.12 & 0.16 \\
\hline Vegetative & 18 & 0 & 320 & -69 abA (12) & $0(0)$ & $251 \mathrm{bA}(13)$ & 132 & 2.44 & 0.33 \\
\hline Fruiting & 18 & 7 & 831 & -100 aA (16) & $9(1)$ & 729 aA (16) & 119 & 7.09 & 1.07 \\
\hline Maturation & 12 & 121 & 106 & $-11 \mathrm{cA}(7)$ & $5(1)$ & $211 \mathrm{bA}(7)$ & 59 & 3.08 & 0.63 \\
\hline \multirow[t]{3}{*}{ Total } & 63 & 128 & 1,405 & $-233 \mathrm{~A}(41)$ & $14(4)$ & $1,287 \mathrm{~A}(42)$ & 418 & 3.58 & 0.54 \\
\hline & & & & $\mathrm{CR}=22 \mathrm{~A}$ & & & & & \\
\hline & & & & $\mathrm{D}=-255 \mathrm{~A}$ & & & & & \\
\hline
\end{tabular}

Means followed by the same lowercase letter in the column, within each treatment, and by the same uppercase letter in the column for the same period between treatments, did not differ by the Tukey test $(\mathrm{p}=0.05)$. Values between brackets correspond to the mean standard deviation $\left(\mathrm{n}=10\right.$ in all periods, except for $\mathrm{U} / \mathrm{D}$ and $\mathrm{ET}_{\mathrm{ac}}$ in the initial and vegetative periods in bare soil, which results from $\mathrm{n}=8$ and $\mathrm{n}=9$, respectively). ${ }^{(1)}$ Daily $\mathrm{ET}_{\mathrm{ac}}$ corrected by the fraction of wetting: [(ET $\mathrm{Ec}_{\mathrm{ac}}$ from the period/number of days in the period) $\times 0.175) .{ }^{(2)}$ Corrected daily $\mathrm{ET}_{\mathrm{ac}} /$ Daily $\mathrm{ET}_{0}$.

explained above, with few days of capillary rise at the end. Although there was rainfall during fruit maturation, stopping irrigation in this period caused water from lower soil layers to enter the control volume. Another important point is the drainage peak on the $54^{\text {th }}$ DAS. This result is atypical, so it is not part of the water management for muskmelon, and it was due to the application of a large irrigation depth caused by technical problems in the water pumping system of the experiment. Although setbacks can occur, the result of drainage for that day was useful because it shows that it is unnecessary to apply a water volume above the maximum soil water storage capacity since the excess will be lost by drainage.

As for the coefficients of variation, which can be calculated from the average standard deviation of each period, values of $28,40,41$, and $72 \%$ were observed for the soil with mulch for the initial, vegetative, fruiting, and maturation stages, respectively. Under bare soil conditions, coefficients of variation of $34,56,50$, and $205 \%$ were observed for the same periods, respectively. By the criteria of Warrick and Nielsen (1980), this variability can be classified as medium in the first three crop stages and high for the end of the cycle. In addition, data variation was much higher in the last period, when rainfalls were recorded, confirming that the greatest variations in the internal drainage process occur in the periods of greatest rainfall (Ghiberto et al., 2011b).

The high variability in drainage is due to the natural or manmade spatial variation in soil physical and hydraulic properties and to the exponential relationship between hydraulic conductivity and soil water content (Silva et al. 2007; Brito et al., 2009). A particular analysis helps to explain the drainage variability observed during maturation. Although it has not been shown experimentally, muskmelon plant architecture may have influenced these results, especially in crops under drip irrigation, which wets only a fraction of the soil. In some places, the leaves may divert rainwater, preventing it from reaching the soil at the point it would reach if there were no interception. In this case, the drainage is underestimated. In contrast, when leaves intercept the rain, they create a preferential flow at the petiole, which may go to where the tensiometers are set up, i.e., instead of being evenly distributed on the soil, the water converges to drain into a single point. Considering that tensiometers are set up on a wet strip and that, under this condition, soil hydraulic conductivity is high, water drains very easily. In this situation, drainage is overestimated in comparison to the average for a given area. Analyzing these 
aspects, even with rigorous control of a farm area, internal drainage with low variability is impossible.

\section{Actual crop evapotranspiration (ET $\left.\mathbf{a c}_{\mathrm{ac}}\right)$}

The actual evapotranspiration for each growth stage of muskmelon in both treatments is found in table 2. The data refer to $\mathrm{ET}_{\mathrm{ac}}$ per wetted area and not per usable area available for the crop. For $\mathrm{ET}_{\mathrm{ac}}$ per area of soil, which is the form usually presented in the literature, one should simply consider the fraction of wetted area in relation to the usable crop area (factor $=0.175$ ). In this case, the $\mathrm{ET}_{\mathrm{ac}}$ values for soil with mulch were equal to $15,42,127$, and $34 \mathrm{~mm}$ for the initial, vegetative, fruiting, and maturation stages, respectively, for a total of $218 \mathrm{~mm}$ throughout the cycle. For the bare soil condition, $\mathrm{ET}_{\mathrm{ac}}$ values of $17,44,127$, and $37 \mathrm{~mm}$ were estimated for the respective periods, adding up to $225 \mathrm{~mm}$ for the entire cycle. The $\mathrm{ET}_{\mathrm{ac}}$ in the initial stage for the treatment with mulch consisted of $7 \%$ of total $\mathrm{ET}_{\mathrm{ac}}$; in the vegetative stage, $19 \%$; in the fruit stage, $58 \%$; and $16 \%$ in the maturation stage. For cultivation in bare soil, the values were $7,19,57$, and $16 \%$, for the same phenological stages, respectively.

In agreement with Hillel (2004), evapotranspiration was the component with the largest magnitude in the soil water balance equation. Considering that the internal drainage below the depth $\mathrm{z}=0.3 \mathrm{~m}$ corresponded to 18 and $15 \%$ of soil water intake for the soil with and without surface coverage, respectively, and that the positive change in storage was small, equivalent to $1 \%$ of the water applied in both treatments, the remainder of the water balance corresponds to $\mathrm{ET}_{\mathrm{ac}}$, which in this case was 81 and $84 \%$ for soil with and without surface coverage, respectively.

Considering the $\mathrm{ET}_{\mathrm{ac}}$ values for each period and 14,286 plants ha ${ }^{-1}$, on average, each plant grown on covered soil had daily evapotranspiration of $0.7 \mathrm{~L}$ in the initial stage, $1.6 \mathrm{~L}$ in the vegetative stage, $4.9 \mathrm{~L} \mathrm{in}$ the fruiting stage, and $2.0 \mathrm{~L}$ in the maturation stage. In bare soil, consumption through evapotranspiration was $0.8,1.7,5.0$, and $2.2 \mathrm{~L}$ in the initial, vegetative, fruiting, and maturation stages, respectively. Over the entire cycle, each melon plant evapotranspired $153 \mathrm{~L}$ in covered soil and $158 \mathrm{~L}$ in bare soil.

Analyzing the $\mathrm{ET}_{\mathrm{ac}}$ per period statistically, there is no significant effect of treatment in either condition. The $\mathrm{ET}_{\mathrm{ac}}$ in covered soil did not differ from that in bare soil, probably because, in the latter, natural prevention of evaporation may have occurred through drying of the soil surface layer. Considering the periods, $\mathrm{ET}_{\mathrm{ac}}$ was lower in the initial stage, equivalent in the vegetative and maturation stages, and higher in the fruiting stage. These results corroborate classic information in the literature (Allen et al., 1998), which states that water demand is low in the initial phase, increases in the period of crop vegetative growth, peaks when fruits are being formed, and decreases in the final stage of the cycle, when fruit maturation and reduction in leaf area occur. Physiologically, provided there is enough water in the soil to meet crop demands, $\mathrm{ET}_{\mathrm{ac}}$ behavior corresponds to the activity of physiological processes related to root, leaf, and fruit formation, i.e., as these processes are triggered over time, $\mathrm{ET}_{\mathrm{ac}}$ increases until it reaches a maximum rate. After that, plant senescence begins and $\mathrm{ET}_{\mathrm{ac}}$ decreases.

Considering $\mathrm{ET}_{\mathrm{ac}}$ corrected for the soil area used by the crop, actual crop coefficient $\left(\mathrm{K}_{\mathrm{ac}}\right)$ values, especially in the initial and vegetative stages, usually differ from the average values in the literature (Table 2). Average $\mathrm{K}_{\mathrm{c}}$ values of 0.35 , $0.70,1.00$, and 0.80 for initial, vegetative, fruiting, and maturation stages, respectively, were reported by Marouelli et al. (2003) for melons in bare soil under drip irrigation. According to these authors, the values in the same stages in covered soil are $0.20,0.60,0.90$, and 0.70 .

This difference can be reasonably explained by the higher water losses through evaporation at the initial and vegetative stages, since much of the wetted area is exposed to solar radiation, the only source of energy available to promote the change of liquid water to vapor. Since the water supply was strictly controlled in this experiment by monitoring soil water matric potential using tensiometers, avoiding excessive wetting of the soil surface, little water was lost through evaporation, which explains $K_{a c}$ values lower than those in the literature. This is confirmed by the values in the fruiting and maturation stages, which are in agreement with the literature. The crop coefficient $\left(\mathrm{K}_{\mathrm{c}}\right)$ is mainly determined by the magnitude of water content in the soil surface when there is little soil cover (Allen et al., 1998). If the surface is always wet, evaporation is high, and therefore $K_{c}$ exceeds the unitary value. On the other hand, if the surface is dry (as occurred in this experiment, due to water control) a break in capillarity takes place, evaporation is restricted, and $\mathrm{K}_{\mathrm{c}}$ can reach values as low as 0.1 without water stress for the crop.

Daily values of actual evapotranspiration are shown in figure 7. $\mathrm{ET}_{\mathrm{ac}}$ in bare soil behaves similarly to $\mathrm{ET}_{\mathrm{ac}}$ in covered soil. Thus, based on the experimental conditions of this study (always keeping soil at field capacity), the use of soil coverage to reduce crop evapotranspiration should be reconsidered, except for the purpose of fruit protection (to prevent the formation of white spots at the bottom of the fruits). Although no significant differences were found between treatments in any of the periods, it appears that in some days, especially in the initial and vegetative periods (in which the soil is not fully covered by the crop), evapotranspiration is always higher in the soil without coverage, which is confirmed by the absolute values of $\mathrm{ET}_{\mathrm{ac}}$ when each period is considered as a whole. 


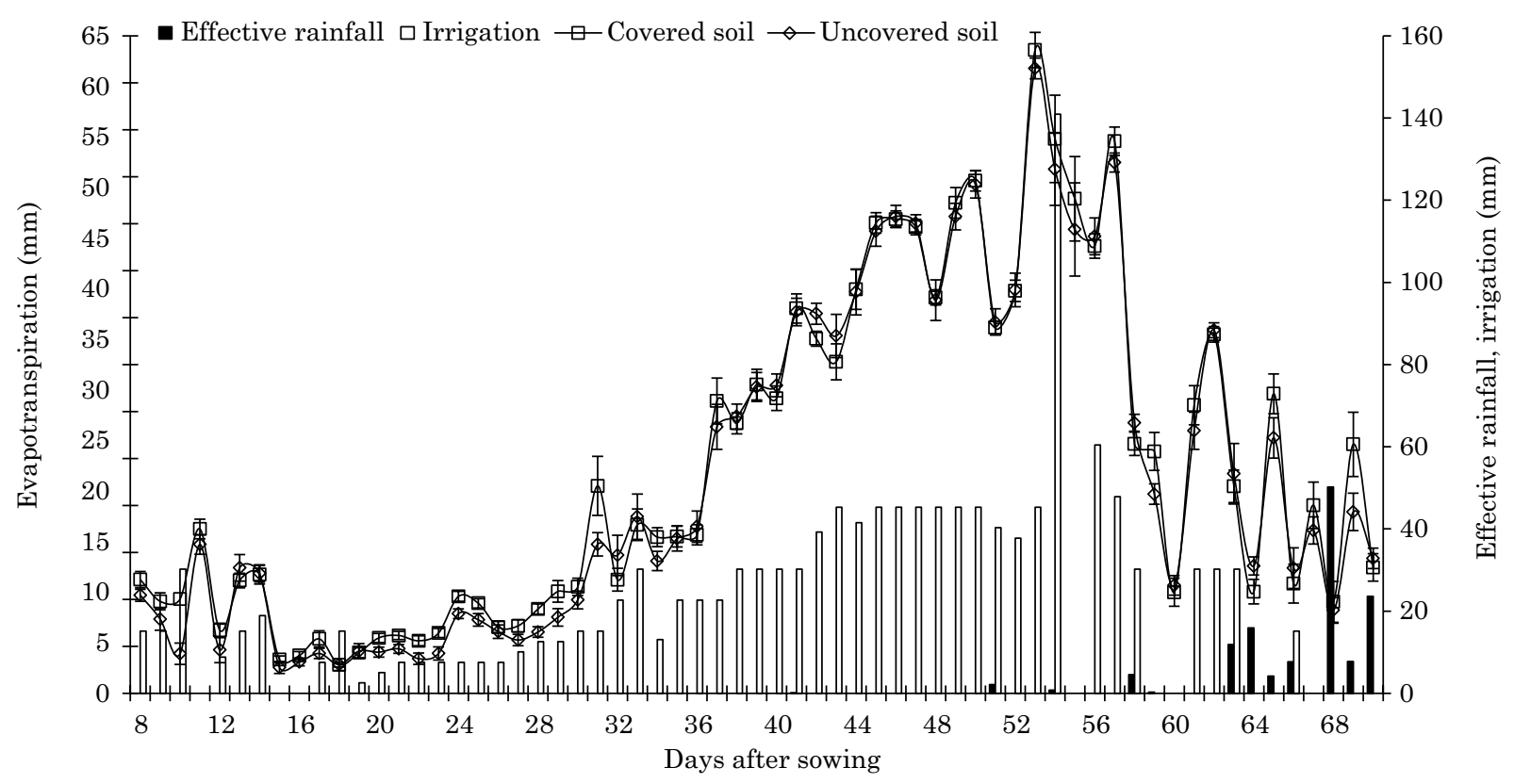

Figure 7. Average daily evapotranspiration, with the corresponding standard deviations, rainfall, and irrigation throughout the muskmelon cycle.

As for the coefficients of variation, which can be calculated from the standard deviations of the means (Table 2), provided that sample sizes are known, they were around $22,14,6$, and $9 \%$ for the initial, vegetative, fruiting, and maturation periods, respectively, for the management practice with mulch. In bare soil, values were $20,16,7$, and $10 \%$ for the same periods. The magnitude of $\mathrm{ET}_{\mathrm{ac}}$ variability for muskmelon in the experimental area was classified as medium in the initial and vegetative periods, and as low in the fruiting and maturation periods (Warrick and Nielsen, 1980).

Although the soil and the $\mathrm{ET}_{\mathrm{ac}}$ estimation processes often have high variability (and error propagation must be considered since $\mathrm{ET}_{\mathrm{ac}}$ is the unknown in the soil water balance equation), the standard deviation of the average $\mathrm{ET}_{\mathrm{ac}}$ propagated throughout the entire cycle was only about $3 \%$ of total crop $\mathrm{ET}_{\mathrm{ac}}$ in both treatments (Table 2). Therefore, in spite of discussions about the difficulties in estimating the components of soil water balance from field experiments, the $\mathrm{ET}_{\mathrm{ac}}$ can be calculated with a significant degree of confidence. Results corroborating this information were reported by Brito et al. (2009), who concluded that the $\mathrm{ET}_{\mathrm{ac}}$ standard deviation did not exceed $15 \%$ of total $\mathrm{ET}_{\mathrm{ac}}$ for the entire cycle of sugarcane.

\section{Water use efficiency}

Regarding water use efficiency, the relationship between yield and the amount of water used can be considered as an index capable of quantifying the impacts caused by management practices
(Ali and Talukder, 2008). For these authors, considering that photosynthetically active radiation is used by plants as energy to convert $\mathrm{CO}_{2}$ into biomass by the process of photosynthesis, using transpired water, the evaporation of soil water does not constitute a factor of production. However, due to difficulties in obtaining independent measurements of crop evaporation and transpiration, evapotranspiration is used as a variable in the determination of water use efficiency. Considering the yields of $32,150 \mathrm{~kg} \mathrm{ha}^{-1}$ and $32,141 \mathrm{~kg} \mathrm{ha}^{-1}$ for covered and bare soils, respectively, and correcting the muskmelon $\mathrm{ET}_{\mathrm{ac}}$ to the soil area available for the crop (factor $=0.175$ ), we found water use efficiencies of 14.75 and $14.26 \mathrm{~kg}$ of fruit per $\mathrm{m}^{3}$ of water.

\section{CONCLUSIONS}

The soil water balance method is efficient in estimating actual evapotranspiration of muskmelon under irrigation.

There was no significant effect of soil coverage on capillary rise, internal drainage, crop actual evapotranspiration, or muskmelon yield compared with the management practice of uncovered soil.

The transport of water caused by evaporation in the uncovered soil was controlled by the break in capillarity at the soil-atmosphere interface, which caused similar water dynamics for the two management systems in the soil studied. 


\section{ACKNOWLEDGMENTS}

Our thanks to WG Fruticultura Ltda. for supporting this study and to the Conselho Nacional de Desenvolvimento Científico e Tecnológico (CNPq) for financial support. To the ad hoc reviewers for the time taken to contribute to the improvement of this manuscript.

\section{REFERENCES}

Abad EPG. Proposta de fixação pelo preço da água para irrigação na agricultura, utilizando a metodologia da programação matemática positiva [tese]. Porto Alegre: Universidade Federal do Rio Grande do Sul; 2007.

Ali MH, Talukder MSU. Increasing water productivity in crop production - A synthesis. Agric Water Manage. 2008;95:1201-13.

Allen RG, Pereira LS, Raes D, Smith M. Crop evapotranspiration: guidelines for computing crop water requirements. Rome: FAO; 1998. (FAO. Irrigation and Drainage Paper, 56).

Anjos JB, Lopes PRC, Faria CMB, Costa ND. Preparo e conservação do solo, calagem e plantio. In: Silva HR, Costa ND, editores. Melão produção: aspectos técnicos. Brasília, DF: Embrapa; 2003. p.35-9. (Frutas do Brasil, 33).

Antonino ACD, Sampaio EVSB, Dall'olio A, Salcedo IH. Balanço hídrico em solo com cultivos de subsistência no semi-árido do Nordeste do Brasil. R Bras Eng Agríc Amb. 2000;4:29-34.

Aydin M. Hydraulic properties and water balance of a clay soil cropped with cotton. Irrig Sci. 1994;15:17-23.

Barros VS, Costa RNT, Aguiar JV. Função de produção da cultura do melão para níveis de água e adubação nitrogenada no Vale do Curu-CE. Irriga. 2002;7:98-105.

Bernardo S, Soares AA, Mantovani EC. Manual de irrigação. $8^{\text {a }}$.ed. Viçosa, MG: Universidade Federal de Viçosa; 2008.

Blake GR, Hartge KH. Bulk density. In: Klute A, editor. Methods of soil analysis. $2^{\text {nd }}$.ed. Madison: American Society of Agronomy, Soil Science Society of America; 1986a. Pt.1, p.363-75. (Agronomy Monography, 9).

Blake GR, Hartge KH. Particle density. In: Klute A, editor. Methods of soil analysis. $2^{\text {nd }}$.ed. Madison: American Society of Agronomy, Soil Science Society of America; 1986b. Pt.1, p.377-82. (Agronomy Monography, 9).

Blight GE. The vadose zone soil-water balance and transpiration rates of vegetation. Géotechnique. 2003;53:55-64.

Brito AS, Libardi PL, Ghiberto PJ. Componentes do balanço de água no solo com cana-de-açúcar, com e sem adubação nitrogenada. R Bras Ci Solo. 2009;33:295-303.

Bruno IP, Silva AL, Reichardt K, Dourado Neto D, Bacchi OOS, Volpe CA. Comparison between climatological and field water balances for a coffee crop. Sci Agric. 2007;64:215-20.

Burt CM. Irrigation water balance fundamentals. USCID: Conference on Benchmarking Irrigation System Performance Using Water Measurement and Water Balances. San Luis Obispo [CA]: 1999. p.1-13.
Clarke D. CropWat for Windows: user guide. 1998 [Accessed on Feb. 18, 1999]. Available at: http://www. tarwi.lamolina.edu. pe/ jgoicochea/Manuales/CROPWAT4W.pdf.

Crisóstomo LA, Santos AA, Raij Bvan, Faria CMB, Silva DJ, Fernandes FAM, Santos FJS, Crisóstomo JR, Freitas JAD, Holanda JS, Cardoso JW, Costa ND. Adubação, irrigação, híbridos e práticas culturais para o meloeiro no Nordeste. Fortaleza: Embrapa Agroindústria Tropical; 2002. (Circular Técnica, 14).

Danielson RE, Sutherland PL. Porosity. In: Klute, A, editor. Methods of soil analysis. $2^{\text {nd }}$.ed. Madison: American Society of Agronomy, Soil Science Society of America; 1986. Pt.1, p.443-61. (Agronomy Monography, 9).

Dourado Neto D, Nielsen DR, Hopmans JW, Reichardt K, Bacchi OOS. Software to model soil water retention curves (SWRC, version 2.00). Sci Agric. 2000;57:191-2.

Gee GW, Bauder JW. Particle-size analysis. In: Klute A, editor. Methods of soil analysis. $2^{\text {nd }}$.ed. Madison: American Society of Agronomy, Soil Science Society of America; 1986. Pt.1, p.383-411. (Agronomy Monography, 9).

Ghiberto PJ, Libardi PL, Brito AS, Trivelin PCO. Components of the water balance in soil with sugarcane crops. Agric Water Manage. 2011b;102:1-7.

Ghiberto PJ, Libardi PL, Brito AS, Trivelin PCO. Leaching of nutrients from a sugarcane crop growing on an Ultissol in Brazil. Agric Water Manage. 2009;96:1443-8.

Ghiberto PJ, Libardi PL, Brito AS, Trivelin PCO. Nitrogen fertilizer leaching in an Oxisol cultivated with sugarcane. Sci Agric. 2011a;68:86-93

Ghiberto PJ, Libardi PL, Trivelin PCO. Nutrient leaching in an Ultisol cultivated with sugarcane. Agric Water Manage. 2015;148:141-9.

Hillel D. Introduction to environmental soil physics. San Diego: Elsevier Academic Press; 2004.

Instituto Brasileiro de Geografia e Estatística - IBGE. Produção agrícola municipal. [Accessed on Nov. 3, 2014] Available at: ftp://ftp.ibge.gov.br/Producao_Agricola/Producao_Agricola_Muni cipal_\%5Banual\%5D/2012/tabelas.pdf/tabela01.pdf.

Instituto Nacional de Meteorologia- INMET. Dados climáticos das estações climatológicas de Mossoró/RN e Jaguaruana/CE. $3^{\circ}$ Distrito de Meteorologia. Recife: 2008.

Klute A. Water retention: laboratory methods. In: Klute A, editor. Methods of soil analysis. $2^{\text {nd }}$.ed. Madison: American Society of Agronomy, Soil Science Society of America; 1986. Pt.1, p.635-62. (Agronomy Monography, 9).

Libardi PL. Dinâmica da água no solo. São Paulo: Edusp; 2012.

Lima JRS, Antonino ACD, Soares WA, Souza ES, Lira CABO. Balanço hídrico no solo cultivado com feijão caupi. R Bras $\mathrm{Ci}$ Agron. 2006;1:89-95

Macgillivray JH. Effect of irrigation on the production of cantaloupes. Proc Am Soc Hortic Sci. 1951;57:266-72.

Marouelli WA, Medeiros JF, Silva WLC, Pinto JM. Irrigação. In: Silva HR, Costa ND, editores. Melão produção: aspectos técnicos. Brasília, DF: Embrapa; 2003. p.51-68. (Frutas do Brasil, 33).

Medeiros FASB, Medeiros JF, Silva MCC, Alves LP, Souza TH, Levien SLA. Necessidade hídrica do meloeiro irrigado com água de diferentes salinidades e cultivado com ou sem cobertura do solo. R Bras Eng Agríc Amb. 2005;9:234-8. 
Medeiros JF, Silva MCC, Sarmento DHA, Barros AD. Crescimento do meloeiro cultivado sob diferentes níveis de salinidade, com e sem cobertura do solo. R Bras Eng Agríc Amb. 2007;11:248-55.

Mota JCA, Libardi PL, Brito AS, Assis Júnior RN, Amaro Filho J. Armazenagem de água e produtividade do meloeiro irrigado por gotejamento, com a superfície do solo coberta e desnuda. $\mathrm{R}$ Bras Ci Solo. 2010;34:1721-31.

Paramasivam S, Alva AK, Fares A. An evaluation of soil water status using tensiometers in a sandy soil profile under citrus production. Soil Sci. 2000;165:343-53.

Pedrosa JF. Cultura do melão. $4^{\mathrm{a}}$.ed. Mossoró: ESAM; 1997. (Apostila).

Porto Filho FQ, Medeiros JF, Sousa Neto ER, Gheyi HR, Matos SJA. Viabilidade da irrigação do meloeiro com águas salinas em diferentes fases fenológicas. Ci Rural. 2006;36:453-9.
Reichardt K, Bacchi OOS, Villagra MM, Turatti AL, Pedrosa ZO. Hydraulic variability in space and time in a dark red latosol of the tropics. Geoderma. 1993;60:159-68.

Reichardt K. Aágua em sistemas agrícolas. São Paulo: Manole; 1990.

Silva AL, Reichardt K, Roveratti R, Bacchi OOS, Timm LC, Oliveira JCM, Dourado Neto D. On the use of soil hydraulic conductivity functions in the field. Soil Till Res. 2007;93:162-70.

Valnir Júnior M, Costa RNT, Aguiar JV. Análise de componentes do balanço hídrico em cultura de caupi (Vigna unguiculata (L) Walp), sob condições de recarga hídrica natural. Irriga. 2001;6:135-53.

van Genuchten MT. A closed-form equation for predicting the conductivity of unsaturated soils. Soil Sci Soc Am J. 1980;44:892-97.

Warrick AW, Nielsen DR. Spatial variability of soil physical properties in the field. In: Hillel D, editor. Applications of soil physics. New York: Academic Press; 1980. p.319-44. 